\title{
Acid maltase levels in muscle in heterozygous acid maltase deficiency and in non-weak and neuromuscular disease controls ${ }^{1}$
}

\author{
ANDREW G. ENGEL AND MANUEL R. GOMEZ \\ From the Mayo Clinicand Mayo Foundation, Department of Neurology and Neuromuscular Research Laboratory, \\ Rochester, Minnesota, U.S.A.
}

SUMMARY Acid maltase (AM) deficiency carriers can be detected by muscle enzyme assay. The assay indicates that, just as in infantile and childhood cases, adult cases of the disease are transmitted by autosomal recessive inheritance. With the maltose hydrolysis assay, in some neuromuscular diseases, muscle AM activity can be as low as in heterozygous AM deficiency. A relatively low muscle AM activity in myxoedema myopathy is confirmed. In human muscle, the $K_{m}$ of the enzyme for maltose hydrolysis is $7 \cdot 2$ to $9 \times 10^{-3} \mathrm{M}$. A modification of the enzyme assay based on this fact is recommended.

A deficiency of lysosomal acid $\alpha$-1,4-glucosidase (acid maltase (AM)) exists in type 2 glycogenosis (Hers, 1963). An increasing body of evidence indicates that the enzyme defect can be associated not only with a fatal disease of infants but also with a syndrome of progressive muscular weakness in children (Hers and van Hoof, 1968) or adults (Engel and Dale, 1968; Hudgson, Gardner-Medwin, Worsfold, Pennington, and Walton, 1968; Engel, 1970). Because the disease appears to be more prevalent than previously recognized and because affected adults are able to reproduce, detection of carriers is important. Detection of heterozygotes in families of affected infants, utilizing unseparated leucocytes, is not consistently reliable (Nitowsky and Grunfeld, 1967). Studies on phytohaemagglutininstimulated lymphocytes may prove to be more useful (Hirschhorn, Nadler, Waithe, Brown, and Hirschhorn, 1969) but the procedure is relatively difficult and requires a tissue culture technique. Low AM levels in muscle had been previously observed in parents of one infant with type 2 glycogenosis (Hug, Garancis, Schubert, and Kaplan, 1966). That a decrease, to below normal, of muscle AM activity also can occur in other neuromuscular diseases was suggested by a recent report of such a decrease in a

\footnotetext{
${ }^{1}$ This investigation was supported in part by Research Grant NB-6277 from the National Institutes of Health, Public Health Service, and by a grant from the Louis W. and Maud Hill Family Foundation.
}

case of myxoedema myopathy(Hurwitz, McCormick, and Allen, 1970). The present report compares muscle AM levels in parents of an infant, a child, and an adult who have AM deficiency with those found in non-weak control subjects and in controls suffering from various neuromuscular diseases.

\section{METHODS}

Biopsy specimens were obtained from limb muscles of seven patients with type 2 glycogenosis (two infants, one child, and four adults), from limb muscles of six heterozygotes (both parents of one of the infants, the child, and one of the adults), from limb, pectoral, or abdominal muscles of 18 patients undergoing surgical procedures but not having muscular weakness, and from limb or pectoral muscles of 31 patients affected by various neuromuscular disorders (listed in legend to Fig. 1). Biopsy specimens were frozen immediately at $-150^{\circ} \mathrm{C}$ and then stored under liquid nitrogen. Frozen tissues were pulverized under liquid nitrogen and homogenized with 9 vol. ice-cold distilled water.

AM activity was measured by both methods described by Hers and van Hoof (1966). In the first procedure, maltose hydrolysis was determined in a reaction system containing $p \mathrm{H} 4$ acetate buffer ( $33 \mathrm{mM})$, maltose $(5 \mathrm{mM})$, and muscle (3.3\%). In additional assays, described below, higher substrate concentrations were used. Incubation was for four hours at $37^{\circ} \mathrm{C}$, and the reaction was stopped by the addition of equimolar amounts of barium hydroxide and zinc sulphate. The reaction product, glucose, was assayed with hexokinase and ATP in the presence of glucose-6-phosphate dehydrogenase and NADP (Slein, 
1965). Enzyme activity was expressed as nanomoles of maltose hydrolysed per minute per gram of muscle. In the second procedure, transglucosylation from labelled maltose into glycogen was assayed by adding $0.1 \mathrm{ml}$. of $5 \%$ aqueous muscle homogenate to $0.25 \mathrm{ml}$. of a solution composed of $p \mathrm{H} 4$ acetate buffer $(20 \mathrm{mM})$, glycogen $(16 \%)$ and maltose-U- ${ }^{14} \mathrm{C}(0.08 \mathrm{mg} / \mathrm{ml}$.). The final reaction system contained $0.55 \mu \mathrm{c}$ of radioactivity. Incubation was for four hours at $37^{\circ} \mathrm{C}$, and the amount of ${ }^{14} \mathrm{C}$ incorporated into glycogen was determined on five-times precipitated glycogen by scintillation counting. The reaction blank contained no muscle homogenate.

\section{RESULTS}

With either the maltose hydrolysis assay in the presence of $5 \mathrm{mM}$ substrate (Table 1 and Fig. 1) or the transglucosylase assay (Table 2), the mean AM level in parents of AM-deficient patients was less than half of the mean AM level in non-weak and in neuromuscular disease controls (differences significant, $P<0.001)$. None of the heterozygotes had muscular weakness or increased serum creatine phosphokinase or glutamic-oxaloacetic transaminase levels. Their muscle biopsies were normal on light microscopic evaluation of frozen and paraffin sections by a variety of techniques, and the muscle glycogen content, determined by the anthrone method, was normal $(0.66$ to $1 \cdot 16 \%)$. Heterozygote and nonweak control AM levels did not overlap in either assay but, with the maltose hydrolysis assay, in four

TABLE 1

ACID MALTASE ACTIVITY WITH 5 mM MALTOSE SUBSTRATE*

\begin{tabular}{lccc}
\hline \multicolumn{1}{c}{ Subjects } & Mean $\pm S E$ & Range & $N$ \\
\hline AM deficiency & $2 \cdot 6$ & $1 \cdot 0-4 \cdot 9$ & 7 \\
Heterozygotes & $17 \cdot 2 \pm 1 \cdot 9$ & $12 \cdot 0-23 \cdot 8$ & 6 \\
Controls: & & & \\
$\quad$ Non-weak & $47 \cdot 1 \pm 4 \cdot 2$ & $28 \cdot 0-84 \cdot 9$ & 18 \\
Neuromuscular disease & $50 \cdot 4 \pm 3 \cdot 7$ & $19 \cdot 0-112$ & 31 \\
\hline
\end{tabular}

*Results are shown as nanomoles of maltose split/min/g muscle.

TABLE 2

TRANSFER OF RADIOACTIVITY FROM LABELLED MALTOSE TO GLYCOGEN*

\begin{tabular}{lcrc}
\hline \multicolumn{1}{c}{ Subjects } & Mean $\pm S E$ & Range & $N$ \\
\hline AM deficiency & 34 & $19-56$ & 6 \\
Heterozygotes & $200 \pm 18$ & $150-265$ & 6 \\
Controls: & $478 \pm 37$ & $310-640$ & 10 \\
$\quad$ Non-weak & $595 \pm 52$ & $287-945$ & 14 \\
$\quad$ Neuromuscular & & & \\
$\quad$ disease & & & \\
\hline
\end{tabular}

* Results are shown as counts/min in glycogen. In all assays, radioactivity of substrate was 861,000 counts $/ \mathrm{min} \pm 1 \%$.

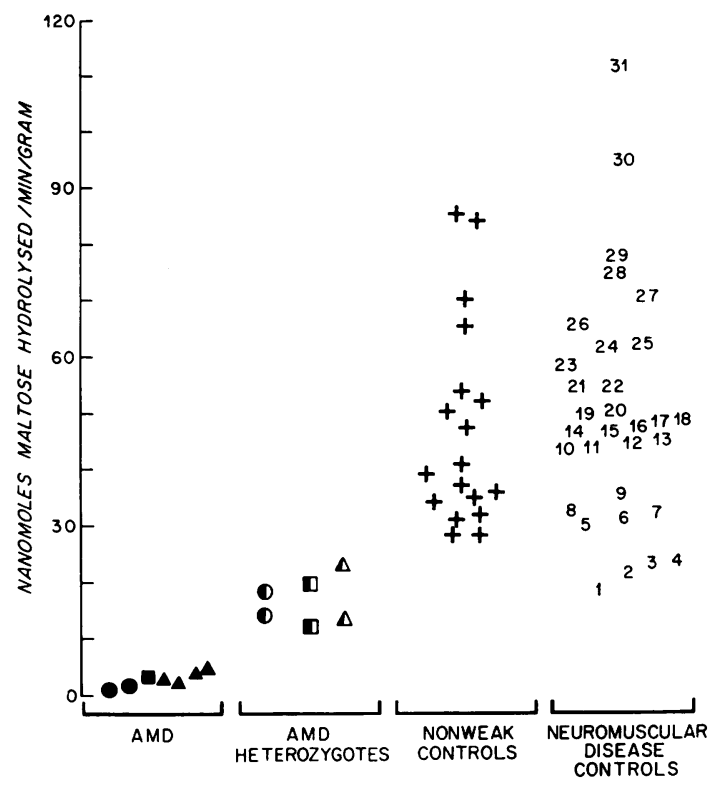

FIG. 1. Acid maltase (AM) activity, with $5 \mathrm{mM}$ maltose as substrate, in deficient subjects, heterozygotes, an $\Phi_{+}$ controls. Solid circles, square, and triangles indicate $\mathrm{S}$ respectively, infants, child, and adults with $A M$ deficiency $\vec{\Phi}+$ Matching half-solid symbols show enzyme activity in both $\square$ parents of these patients. Neuromuscular disease controts are represented by numbers as follows: myotonia congenitof 1 and 7; myxoedema myopathy, 2 and 3; primary hype? kalaemic periodic paralysis, 4, 9, and 11; limb-girdl dystrophy, 5, 13, 14, 21, and 28; spinal muscular atrophy 6 and 24; myotonic dystrophy, 8 and 16; primary hypokalaemic periodic paralysis, 20 and 29; polymyositis (steroid-treated), 10; polymyositis (untreated), 12, 22, 23, and 26; facioscapulohumeral dystrophy, 15; familial neuromyopathy, 17; myasthenic syndrome, 18; dystrophy of ocular, pharyngeal, and distal muscles, 19; myopathy, type undetermined, 25; Duchenne's dystrophy, 27; granulomatous myopathy, 30; myasthenia gravis, 31 .

of 27 neuromuscular disease controls (one of two with myotonia congenita, two of two with myxoedema myopathy, and one of three with hyperkalaemic periodic paralysis), the AM activity (19, 22,23 , and $24 \mathrm{n}-\mathrm{mole} / \mathrm{min} / \mathrm{g}$, respectively) was in the heterozygote range (Fig. 1). The muscle glycogen content in these four controls was in the normal range $(0.8$ to $1.1 \%)$. Two of these four controls (case 3 , myxoedema myopathy, and case 4 , hyperkalaemic periodic paralysis) were also represented in the transglucosylase assay. Although with this assay the heterozygote and neuromuscular disease control AM levels did not overlap, a patient with myxoedema myopathy showed the lowest activity (287 counts/ min) among the neuromuscular disease controls. 
Because purified AM preparations from rat liver (Jeffrey, Brown, and Brown, 1967; Auricchio, Bruni, and Sica, 1968) and from human kidney (Auricchio et al., 1968) were found recently to have $K_{m}$ values of $5 \times 10^{-3} \mathrm{M}$ and $13.6 \times 10^{-3} \mathrm{M}$, respectively, with maltose as substrate, it seemed possible that the enzyme in muscle homogenates was suboptimally active at the $5 \mathrm{mM}$ substrate concentration originally recommended by Hers (1963). Maltose hydrolysis was therefore determined with increasing concentrations of maltose in three cases of AM deficiency in adults, in six heterozygotes and in two non-weak and two neuromuscular disease controls (Fig. 2). A slight increase in detectable enzyme level occurred in two of three deficient subjects. In one of these two subjects and in all the other subjects, reaction velocities increased along the paths of rectangular hyperbolas; the Lineweaver-Burk plots of $1 / \mathrm{v}$ against $1 / \mathrm{s}$ provided $\mathrm{K}_{\mathrm{m}}$ values of $7 \cdot 2$ to $9.0 \times 10^{-3} \mathrm{M}$. The reaction velocities appeared to approach a plateau in the presence of $50 \mathrm{mM}$ maltose. With still higher substrate concentration, traces of glucose in the maltose (one part in 500) resulted in relatively high reagent blanks, and substrate inhibition of maltose hydrolysis was encountered in some assays.

Results of all maltose hydrolysis assays in the presence of $50 \mathrm{mM}$ maltose are shown in Table 3 . The mean heterozygote AM level was again significantly lower $(P<0.001)$ than the mean AM level in either control group. Neuromuscular disease control cases 3 (myxoedema myopathy) and 4 (hyper-
TABLE 3

ACID MALTASE ACTIVITY WITH 50 mM MALTOSE SUBSTRATE*

\begin{tabular}{lccc}
\hline \multicolumn{1}{c}{ Subjects } & Mean $\pm S E$ & Range & $N$ \\
\hline AM deficiency & $4 \cdot 0$ & $0 \cdot 9-8 \cdot 9$ & 5 \\
Heterozygotes & $37 \cdot 8 \pm 4 \cdot 5$ & $24 \cdot 9-53 \cdot 2$ & 6 \\
Controls: & & & \\
$\quad$ Non-weak & $93 \cdot 0 \pm 8 \cdot 4$ & $62 \cdot 8-122 \cdot 8$ & 8 \\
Neuromuscular disease & $117 \cdot 6 \pm 10 \cdot 3$ & $50 \cdot 4-219 \cdot 0$ & 18 \\
\hline
\end{tabular}

*Results are shown as nanomoles of maltose split/min/g muscle.

kalaemic periodic paralysis) were again represented in this assay. The AM activity in the myxoedema myopathy case $(50.4 \mathrm{n}-\mathrm{mole} / \mathrm{min} / \mathrm{g})$, but in no other control, was in the heterozygote range.

\section{DISCUSSION}

The fact that muscle AM levels in the parents of the affected adult were as low as in the parents of the affected infant and the affected child indicates that the adult variety of the disease is also transmitted by recessive inheritance. Adult cases of AM deficiency therefore represent homozygotes rather than clinical manifestations in incompletely recessive heterozygotes, as previously suggested (Hudgson et al., 1968). The significance of the decreased AM levels in some of the neuromuscular disease controls is not clear. That it could be a consequence of the primary disease is supported by the finding of lower-than-

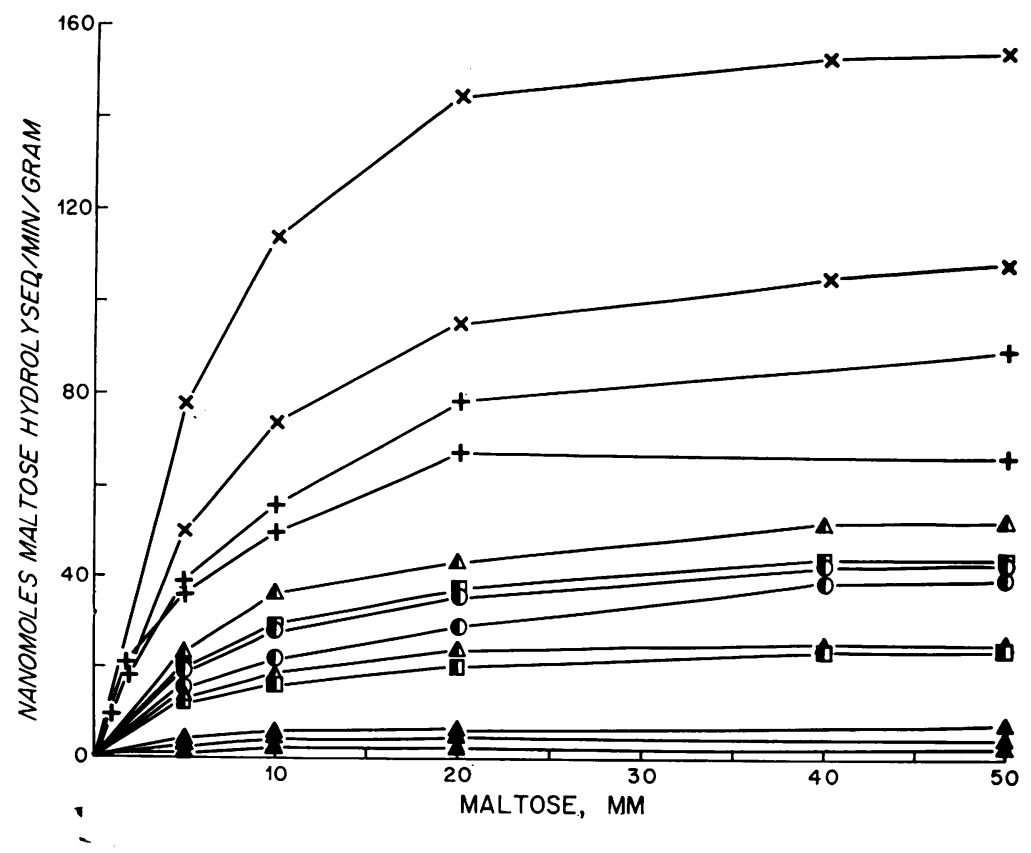

FIG. 2. Effect of increasing concentration of maltose on acid maltase ( $A M)$ activity. + and $\times$ represent non-weak and neuromuscular disease controls, respectively. Other symbols have same meaning as in Fig. 1. 
normal levels of other glycolytic enzyme activities in myxoedema (Krause and Wollenberger, 1968), muscular dystrophy (Ronzoni, Berg, and Landau, 1960; Cooper and Miller, 1962; Schapira and Dreyfus, 1963; Di Mauro, Angelini, and Catani, 1967), and neurogenic atrophy (Di Mauro et al., 1967). Finally, although in each assay the mean muscle AM levels of heterozygotes and non-weak controls differed significantly, the highest heterozygote AM values were only slightly lower than the lowest non-weak control values. Therefore, while muscle AM assay can be considered to be useful in carrier detection, the heterozygous state should be excluded with caution when enzyme values in the lower range of non-weak control values are encountered.

\section{REFERENCES}

Auricchio, F., Bruni, C. B., and Sica, V. (1968). Further purification and characterization of the acid $\alpha$-glucosidase. Biochem. J., 108, 161-167.

Cooper, A. C., and Miller, J. R. (1962). Progressive muscular dystrophy: a review. Rev. canad. Biol., 21, 337-351.

Di Mauro, S., Angelini, C., and Catani, C. (1967). Enzymes of the glycogen cycle and glycolysis in various human neuromuscular disorders. J. Neurol. Neurosurg. Psychiat., 30, 411-415.

Engel, A. G. (1970). Acid maltase deficiency in adults: Studies in four cases of a syndrome which may mimic muscular dystrophy or other myopathies. Brain, 93, 599-616.

Engel, A. G., and Dale, A. J. D. (1968). Autophagic glycogenosis of late onset with mitochondrial abnormalities: light and electron microscopic observations. Mayo Clin. Proc., 43, 233-279.

Hers, H. G. (1963). $\alpha$-Glucosidase deficiency in generalized glycogen-storage disease (Pompe's disease). Biochem. J., 86, 11-16.
Hers, H. G., and van Hoof, F. (1966). Enzymes of glycogen degradation in biopsy material. Meth. Enzym., 8, 525-532.

Hers, H. G., and van Hoof, F. (1968). Glycogen-storage diseases: Type II or type VI glycogenosis. In Carbohydrate Metabolism and Its Disorders, vol. 2, pp. 151-168. Edited by F. Dickens, P. J. Randle, and W. J. Whelan. Academic Press: New York.

Hirschhorn, K., Nadler, H. L., Waithe, W. I., Brown, B. I., and Hirschhorn, R. (1969). Pompe's disease: detection of heterozygotes by lymphocyte stimulation. Science, 166, 1632-1633.

Hudgson, P., Gardner- Medwin, D., Worsfold, M., Pennington, R. J. T., and Walton, J. N. (1968). Adult myopathy from glycogen storage 'disease due to acid maltase deficiency. Brain, 91, 435-462.

Hug, G., Garancis, J. C., Schubert, W. K., and Kaplan, S. (1966). Glycogen storage disease, types II, III, VIII, and IX: A biochemical and electron microscopic analysis. Amer. J. Dis. Childh., 111, 457-474.

Hurwitz, L. J., McCormick, D., and Allen, I. V. (1970). Reduced muscle $\alpha$-glucosidase (acid-maltase) activity in hypothyroid myopathy. Lancet, 1, 67-69.

Jeffrey, P. L., Brown, B. I., and Brown, D. H. (1967). Purification of lysosomal $\alpha$-glucosidases (abstract). Fed. Proc., 26, 345 .

Krause, E.-G., and Wollenberger, A. (1968). Abhängigkeit der Aktivität einiger Enzyme des Glykogenstaffwechsels des Skeletmuskels der Ratte vom Schilddrüsenstatus. Acta biol. med. germ., 21, 615-624.

Nitowsky, H. M., and Grunfeld, A. (1967). Lysosomaए $\infty$ $\alpha$-glucosidase in type II glycogenosis: activity in leuko은 cytes and cell cultures in relation to genotype. J. lab. clin Med., 69, 472-484.

Ronzoni, E., Berg, L., and Landau, W. A. (1960). Enzyme studies in progressive muscular dystrophy. Res. Publ. Ass Res. nerv. ment. Dis., 38, 721-729.

Schapira, G., and Dreyfus, J.-C. (1963). Biochemistry of progressive muscular dystrophy. In Muscular Dystrophy in Man and Animals, pp. 47-87. Edited by G. H. Bourne and M. N. Golarz. Karger: Basle.

Slein, M. W. (1965). D-glucose: Determination with hexo= kinase and glucose-6-phosphate dehydrogenase. In Methods of Enzymatic Analysis, pp. 117-130. Edited by H.-U. Bergmeyer. Academic Press: New York. 